\title{
Comparative Pharmacognostic Screening of Tribulus terrestris L. and Tribulus lanuginosusL.
}

\author{
${ }^{1}$ Snehal N. Dhawale and D. A. Dhale ${ }^{2 *}$
}

${ }^{1}$ Department of Botany, MatoshriSubhadrabaiPatil Arts, Science and Late PandurangThakare Commerce College, Manora, Dist.Washim- 444404 (M.S) India.

${ }^{2}$ Post-Graduate Department of Botany, SSVPS's, L. K. Dr. P. R. Ghogrey Science College, Dhule-424001 (M.S.) India.

\begin{abstract}
The genus Tribulusbelongs to the family Zygophyllaceae comprises approximately 25 species that grow as prostrate. This study will collect Tribulus terrestris L. and Tribulus lanuginosus $L$. and analyse their macroscopic, microscopic and phytochemical properties. Selected plant species were collected from three geographical locations in Maharashtra State, India.To confirm the quality and authenticity of plants, standard pharmacognostic procedures described in standard reference books were used to conduct a comparative analysis of Tribulussps. The current study examines pharmacognostic studies on its numerous parts, such as the stem, leaf, flower and fruit.The Study showsT. terretris L., leaf sections demonstrate the presence of unicellular trichomes that are substantially denser in $T$. lanuginosus L. In numerous tests for qualitative analysis of distinct Tribulussps.phytochemical substances such as alkaloids, starch, carbohydrates, tannin, saponins, glycosides, phenol, flavonoids, and proteins were found to be present.
\end{abstract}

Keywords: Tribulus terrestris, Tribulus lanuginosus, Pharmacognosy, Microscopic.

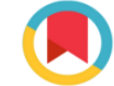

Check for updates
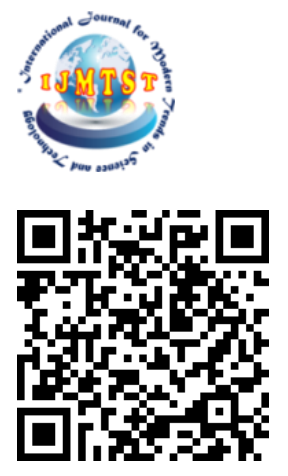

To Cite this Article:

DOI of the Article: $\underline{\text { https://doi.org/10.46501/IJMTST0708030 }}$

Available online at: http://www.ijmtst.com/vol7issue08.html

As per UGC guidelines an electronic bar code is provided to seure your paper

Snehal N. Dhawale and D. A. Dhale.Comparative PharmacognosticScreening of Tribulus terrestris L. and Tribulus lanuginosus L. International Journal for Modern Trends in Science and Technology 2021, 7, 0708046, pp. 175-181. https://doi.org/10.46501/IJMTST0708030

Article Info.

Received: 09 July 2021; Accepted: 07August 2021; Published: 17August 2021 


\section{INTRODUCTION}

India boasts the world's greatest and most diverse floral diversity,including many species that seem same. Furthermore, India is a large country with many different languages spoken on a regular basis. As a result, a single plant species has a multiplicity of names, producing uncertainty in the identification of many plants mentioned in folklore.

The Zygophyllaceae family includes trees, shrubs, and plants that are typically found in arid and semi-arid regions of the tropics and subtropics. The genus Tribulus, which belongs to the Zygophyllaceae family, has about 25 species that grow prostrate. The opposing, typically pinnately split leaves. The majority of them are herbs or shrubs, although a few are trees. Caltrops are adapted to desert environments and are uncommon in northern latitudes.A typical flower from this family is regular and bisexual, with five sepals and five petals (occasionally four of each) and either five, ten, or fifteen stamens. The ovary is at a higher position. It is made up of 5 joined carpels (syncarpous) that are connected by partition walls to produce an equal number of chambers.It matures as a capsule with 2 or more seeds per cell, or rarely as a drupe. Worldwide there are about 30 genera and 250 species. (Porter, 1971).

Tribulus terrestris L.: It is a plant commonly known as 'Puncture vine Caltrop', or 'Ji Li', (and many other names including goat's-head, bindii, bullhead, burragokharu, bhakhdi, caltrop, small caltrops, cat's-head, devil's eyelashes, devil's-thorn, devil's-weed, puncture vine, puncture vine and tack weed. The plant is an annual. Flowering is starting from May to August, fruiting period from June to September(Naik, 1998).

Distribution: Common weed in a wasteland, roadsides ad fallow lands of sandy and gravelly habitat.

Tribulus lanuginosus L.: It is mostly located in dry regions.It's a prostrate plant. Leaflets are mostly in equal in pairs like 3-6. It consists of a large style as compare to T. terretris L. Flowering starts from June to December or sometimes throughout the year. (NayarandGiri, 1982).

Distribution: In most of the states of India like Maharashtra, Gujarat, etc.

Data sources of different disciplines like anatomy, phytochemistry, embryology, palynology, etc. are required for the proper identification of species. A comparative account of Tribulussps. is not available on different data sources. Hence in the present studyMorphological and anatomical studies were carried out with the following objective.To study morphological and anatomical features, differences, similarities in Tribulussps.

\section{MATERIAL AND METHODS}

\section{Collections and authentication of plants:Tribulus} terrestrisL.and Tribulus lanuginosusL.(Zygophyllaceae family)were collected from the following Maharashtra areas: BaramatiDistrict, Pune, Majalgaon dam, Beed district, Solapur, Sautada waterfall, Patoda district, Beed district.The plants were botanically identified and confirmed by the Taxonomist using the flora of Maharashtra (Singhand Karthikeyan, 2000)atDepartment ofBotany, SavitribaiPhule Pune University, Pune (MS).

Morphological study: Fresh plant material was used to conduct a morphological study of the given plant material. The ovary was dissected to isolate each character of this different species for the identification of morphological traits, primarily blooming characters. A light microscope was utilised to understand the microscopic features.

Anatomical study: A double staining approach was used to analyse the anatomical structure of the provided plant material. By preparing thin sections of leaf and stem from fresh plant material, microscopic examinations were carried out. A tiny blade was utilised to section the offered plant material. A projection microscope was used to obtain photographs at various magnifications (Dhale, 2011).

Drying and grinding: The plants were dried at room temperature after being collected. With the use of a grinder, the dry components were ground to a powder and stored in a container. The container was then placed in a cool, dark location until extraction could begin (Dhaleet al., 2010).

\section{Phytochemical analysis:}

The phytochemical study of selected plants Tribulus lanuginosus $L$. and $T$. terrestris $L$. were carried out followed by the given method.

Qualitative analysis for Starch (Peach and Tracy, 1955)

The 3 gm of grinded plant material were kept for 24 hours in dark conditions into $30 \mathrm{ml}$ of distilled water. 
The water is then purified using filter paper. Further tests were performed on the filtrate. The test for starch was conducted with iodine in $2 \%$ aqueous potassium iodide.

Qualitative analysis for Protein / Millions test (Treaseand Evans, 2002)

The millions reagent is a solution of mercuric nitrate in a nitric acid 9 if react specifically with any phenol compound in which 3 and 5 positions were unsubstituted. The protein gives a red color with millions of reagents ( $150 \mathrm{~g}$ in 1 lit, 15\% $\mathrm{H}_{2} \mathrm{SO}_{4}$ ). About 2 $\mathrm{ml}$ of the test solution was boiled with a few drops of millions of reagents and observe the color.

\section{Qualitative analysis for Saponins (Treaseand Evans,} 2002)

A violently shaken water extract of the plant material (with few drops of natural water). Saponins were detected by a persistent lather (foam).

Qualitative analysis for Tannin (Treaseand Evans, 1972)

The presence of tannins was tested in a water extract from plant material that had been treated with ferric chloride (acidic).

\section{Qualitative analysis for Steroids}

\section{(Liebermann-Burchard's test)}

The plant material powder dissolved in $2 \mathrm{ml}$ of Chloroform $\left(\mathrm{CHCl}_{3}\right)$ in a dry clean test tube $1 \mathrm{ml}$ of acetic anhydride and 2 drops of conc. Sulphuric acid $\left(\mathrm{H}_{2} \mathrm{SO}_{4}\right)$ was added. The solution became red then blue and finally, bluish-green color indicated the presence of steroids.

\section{Analysis for Alkaloids (Homersleg, 1950)}

The plant material was pulverized into powder with the help of a grinder. The alkaloids were extracted in absolute alcohol then it was filtered through Whatman No. 1 filter paper. Filtrate served as the source of alkaloids. They were tested with different reagent as follow.

\section{Mayer's Reagent}

$1.3 \mathrm{~g}$ of Mercuric Chloride $\left(\mathrm{HgCl}_{2}\right)$ and $5 \mathrm{ml}$ of potassium iodide (KI) were dissolved separately in 60 $\mathrm{ml}$ of distilled water respectively and both the solutions were mixed and diluted in $100 \mathrm{ml}$.

Wagner's Reagent
$1.27 \mathrm{~g}$ iodine and $2 \mathrm{~g}$ potassium iodide dissolved in 50 $\mathrm{ml} \mathrm{DW}$ the two reagents were mixed together to generate a final volume of $100 \mathrm{ml}$.

\section{Hager's reagent}

$10 \mathrm{ml}$ Picric acid dissolved in $10 \mathrm{ml}$ DW. Dissolved $1 \mathrm{~g}$ of Picric acid in $100 \mathrm{ml}$ of $\mathrm{H}_{2} \mathrm{O}$.

\section{Qualitative analysis for Phenol (Treaseand Evans, 1983)}

The powder sample (200mg) homogenized with $10 \mathrm{ml}$ of $80 \%$ ethanol \& centrifuged. The supernatant $(5 \mathrm{ml})$ was treated with a mixture of an equal volume of $5 \%$ Ferric chloride.The appearance of blue color indicated the presence of phenol.

Qualitative analysis for Flavonoids (Fransworth, 1960)

A few drops of concentrated hydrochloric acid $(\mathrm{HCl})$ and magnesium $(\mathrm{Mg})$ turnings were added to $1 \mathrm{~mL}$ ethanol extract. Flavonoid presence was identified by the formation of a pink or magenta tint.

Qualitative analysis for Glycolysis (Harbone, 1973)

The plant material was extracted in absolute alcohol. Whatman No. 1 filter paper was used to filter it. Take 2-3 mL of filtrate and slowly pour in an equal volume of warm benzene from the test tube's edge. The presence of Glycolysis was shown by the development of a white precipitate around the borders.

\section{RESULTS AND DISCUSSION}

Authentication is the initial stage in assuring the quality of starting material. As a result, there has been a remarkable increase in the standardisation of selected medicinal plants with therapeutic promise in recent years. Despite current technology, pharmacognostic investigations are more reliable for identifying plant medicines. According to the World Health Organization, the macroscopic and microscopic description of a medicinal plant is the first step in determining its identity and degree of purity, and should be completed before any tests are conducted (Dhale and Kalme, 2012). Results are as follows:

Morphological Characters of T.terrestris:A habit of the T. terretris is Prostrate, annual herbs; stems are usually $30-75 \mathrm{~cm}$ long, tapering at both the end, pubescent and glabrous. Leaves are in unequal pairs i.e. 5-7 on each leaflet, petioles 5-10 mm long; stipules are subulate, hairy. Leaflets are 3-6 pairs, 5-10 mm long, cuneate or rounded at base, mucronate, pubescent on 
both surfaces; petioles are very short; flowers are bisexual, complete, yellow in color, axillary or leaf-opposed, pedicels long, hairy. Sepals are 5 in no., valvatetype of aestivation, acute, and pubescent outside. Petals are 5 in no., valvate, yellow, obovate, and twice as long as the sepals. Ovary pentacarpellary, pubescent, superior; style is very short. Fruit is globose, with 5, woody mericarp; lateral spines much longer than the basal ones. Seeds are many (Table1; Plate 1).

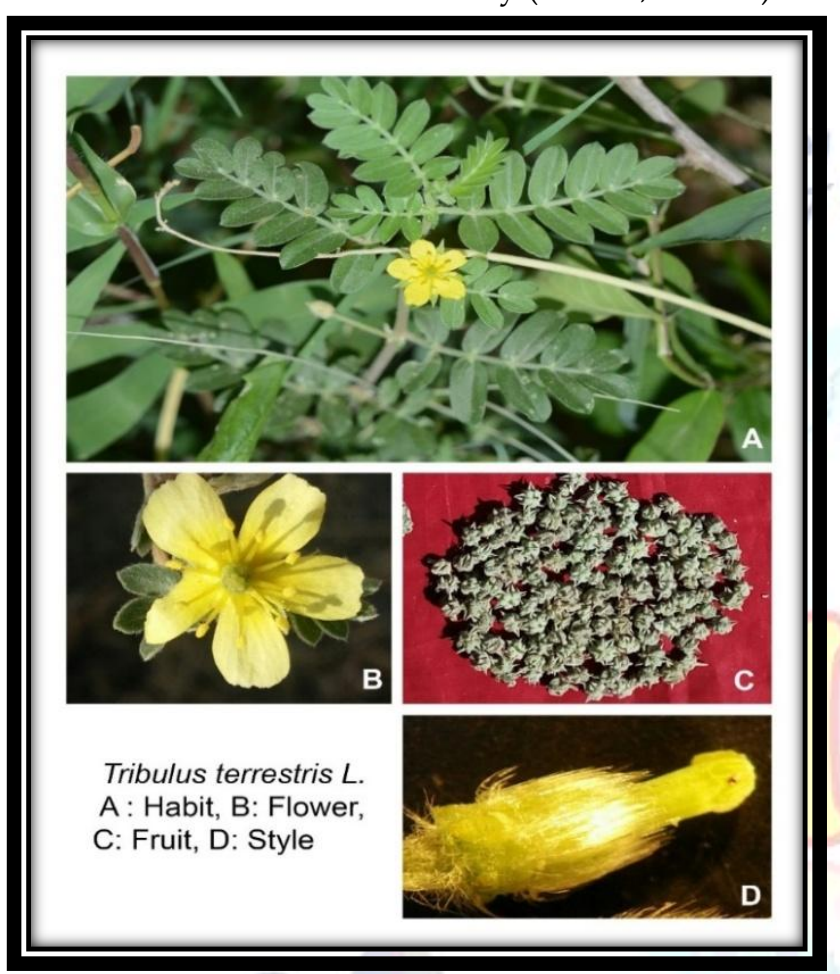

Plate 1: Habit of T. terretrisL.

Morphological Characters of T.lanuginosus:It is a Prostrate or procumbent, white tomentose herb; its branches are $15-60 \mathrm{~cm}$ or more long. Leaves are compound, opposite, abruptly cunate, often unequal in pair, petioles are long; stipules lanceolate and hairy, Leaflets are equal in no. i.e. 3-6 pairs, long, oblique at base, mucronate, sericeo-villous on both surfaces, reticulate venation; petioles are very short. Flowers are bisexual, bracteates, pentamerous, actinomorphic, complete, hypogynous, pedicels long, hairy, sepals lanceolate, long, acute, and hairy; inflorescence is axillary or solitary; inflorescence is axillary or solitary; inflorescence is axillary or solitary; inflorescence is axillary or solitary; inflorescence The five sepals are whitish-green and polysepalous, indicating valvate aestivation. Petals are five in number, polypetalous with valvate aestivation, yellow in colour, oblong-obovate in shape, twice as long as sepals, and hairy.The ovary is superior pentacarpellary and syncarpous, with 10 stamens, long filaments, and anthers linked to filaments. Densely hairy, with a thick style. The globose fruit has five woody, spinous, and muriculate mericarps, two of which are substantially longer than the two basal ones(Table1; Plate 2).

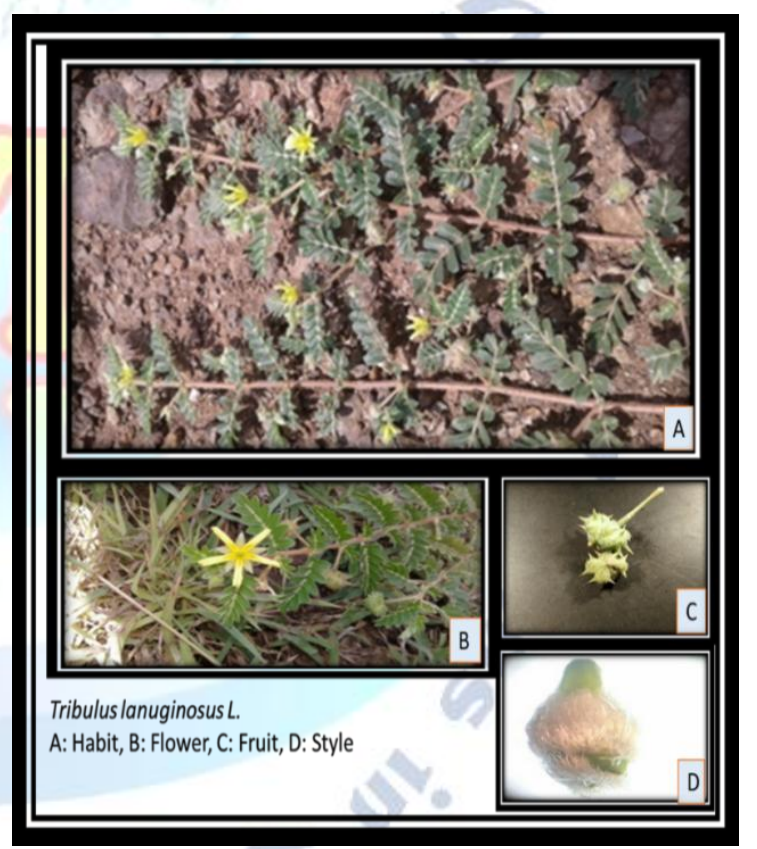

Plate 2: Habit of T. lanuginosus L

Table 1: Morphological similarities and differences between Tribulussps.

\begin{tabular}{lll}
\hline $\begin{array}{l}\text { Morphological } \\
\text { characters }\end{array}$ & T. terrestrisL. & T. lanuginosusL. \\
\hline Habit & Herb, annual, prostrate to procumbent. & $\begin{array}{l}\text { Herb, annual or biennial, usually prostrate, } \\
\text { silky pubescent. }\end{array}$ \\
\hline Stem & $\begin{array}{l}\text { Stem hairy, branched, hirsute to } \\
\text { sericeous. }\end{array}$ & $\begin{array}{l}\text { The stem is silky pubescent, tomentose in } \\
\text { color. }\end{array}$ \\
\hline Leaf & $\begin{array}{l}\text { Leaves are opposite, leaflets 8-14, ovate } \\
\text { to elliptic, oblique, acute or obtuse, } \\
\text { stipules subulate to falcate. }\end{array}$ & $\begin{array}{l}\text { Leaves are opposite, leaflets 6-12, } \\
\text { elliptic-oblong, oblique, acute, stipules } \\
\text { lanceolate. }\end{array}$ \\
\hline Leaf hairs & Hairy & Silky hairy \\
\hline
\end{tabular}




\begin{tabular}{|c|c|c|}
\hline Leaf size & $4-11 \times 2-5 \mathrm{~mm}$ & $3-10 \times 2-5 \mathrm{~mm}$ \\
\hline Leaf color & Silky green & Silky green \\
\hline Inflorescence & Solitary, axillary & Solitary, axillary \\
\hline Flower & $\begin{array}{l}\text { Bisexual, solitary, yellow in color, } \\
\text { pedicel long } 10 \mathrm{~mm} \text {. }\end{array}$ & $\begin{array}{l}\text { Bisexual, solitary, yellow in color, pedicel } \\
\text { long more than } 10 \mathrm{~mm} \text {. }\end{array}$ \\
\hline Calyx(sepals) & 5 sepals, ovate to lanceolate, acute. & 5 sepals, lanceolate. \\
\hline Corolla(petals) & 5 petals, ovate. Yellow in color & $\begin{array}{l}5 \text { petals, obovate-oblong, obtuse-truncate. } \\
\text { Yellow in color }\end{array}$ \\
\hline Androecium & 10 stamen, anthers oblong. & $\begin{array}{l}10 \text { stamen, anthers oblong. } \\
\text { Intrastaminal glands triangular, free; } \\
\text { extrastaminal glands thick, truncate. }\end{array}$ \\
\hline Gynoecium & $\begin{array}{l}\text { Ovary superior, style } 1 \mathrm{~mm} \text { long, } \\
\text { stigma } 5 \text { rayed, slightly asymmetrical. } \\
\text { Style glabrous. } \\
\text { Style shorter than ovary. }\end{array}$ & $\begin{array}{l}\text { Ovary superior, style } 2.5 \mathrm{~mm} \text { long, stigma } \\
\text { faintly } 5 \text { rayed or sub-capitate. } \\
\text { Style glabrous. } \\
\text { Style longer than ovary. }\end{array}$ \\
\hline Fruit & $\begin{array}{l}\text { Fruits with spiny mericarps, spines } 4 \text { or } \\
2 \text {. }\end{array}$ & $\begin{array}{l}\text { Fruits with spiny mericarps, } \\
\text { Spines 2-4. }\end{array}$ \\
\hline
\end{tabular}

\section{Anatomical study}

One-layer epidermis, parenchymatous cortex, pericyclic fibres above collateral vascular bundles, primary and secondary xylems and phloem, short medullary rays, and large parenchymatous pith make up the stems. The leaflets are dorsiventral, displaying the kranz structure as well as various hair types.

The focus of this research was to characterise and compare the anatomical properties of $T$. terrestris and $T$. lanuginosus in order to serve as a useful source of knowledge and contribute to the development of a standard for determining the quality and authenticity of these plants in future research. There have been no anatomical research on any morphological part of $T$. lanuginosus, according to the literature review.

T.S.Stem ofT. terretrisL.: The transverse section of the stem of T.terrestris is circular in outline. The outermost layer is the epidermis, it is formed of one layer of small polygonal cells covered by thick cuticles. After the epidermis, there is the cortical region which is formed by 1-3 layers of a thick parenchymatous cell which are isodiametric with small intercellular spaces. The hypodermis is present just after the cortical region(Elkamali et al.,2016). The pericycle is present just after the hypodermis. Just below the pericycle lies the primary and secondary phloem. Large vessels are divided by xylem parenchyma cells in the secondary xylem. The vascular bundles are in close proximity to one another. The pith is made up of compactly packed parenchyma cells and is broad (Table 2; Plate 3).

T.S.stem ofT. lanuginosusL.: The stem of T. lanuginosus has a round outline in transverse section. The epidermis is the outermost layer, which is made up of small polygonal cells covered in thick cuticles. The cortex is made up of two to three layers of thick parenchymatous cells that are isodiametric and have small intercellular gaps. Just above the pericyclic fibres, primary and secondary phloem can be seen.The fascicular and interfascicular cambiums are joined to form a vascular cambium ring that is 3-5 cells thick. The primary and secondary xylem are both present; the primary xylem is made up of xylem vessels and is found in the inner part of the vascular bundle (Table 2; Plate 3). The vascular bundles are in close proximity to one another (Elkamali et al.,2016).

Comparative Study of Leaf sections ofTribulussps.:One layer of polygonal epidermal cells of various sizes forms the transverse section of the leaflet of the both species. T. terretris leaflets are isobilateral and amphistomatous, according to the epidermal investigation. (Treaseand Evans, 1983).There 
are hairs that are unicellular, simple glandular, and non-glandular. T. terretris has sparse hairs, whereas $T$. lanuginosus has thick hairs that are larger than $T$. terretris. Thick cuticles protect the epidermal cells. The leaflets are dorsiventral, with one layer of palisade cells, which are long compact chlorenchyma cells, following the upper epidermis.Between the palisade and spongy parenchyma layers is where the vascular bundle can be discovered. A sheath of chlorenchyma cells surrounds the vascular bundles (Kranz structure). The vascular bundles are created by the xylem connecting to the upper epidermis and the phloem connecting to the lower epidermis. The cells in the lower epidermis are smaller than those in the upper epidermis, and epidermal hairs are denser.Reduced stomatal density and the presence of trichomes are adaptations found in plants that are water-stressed (Table 2; Plate 3).

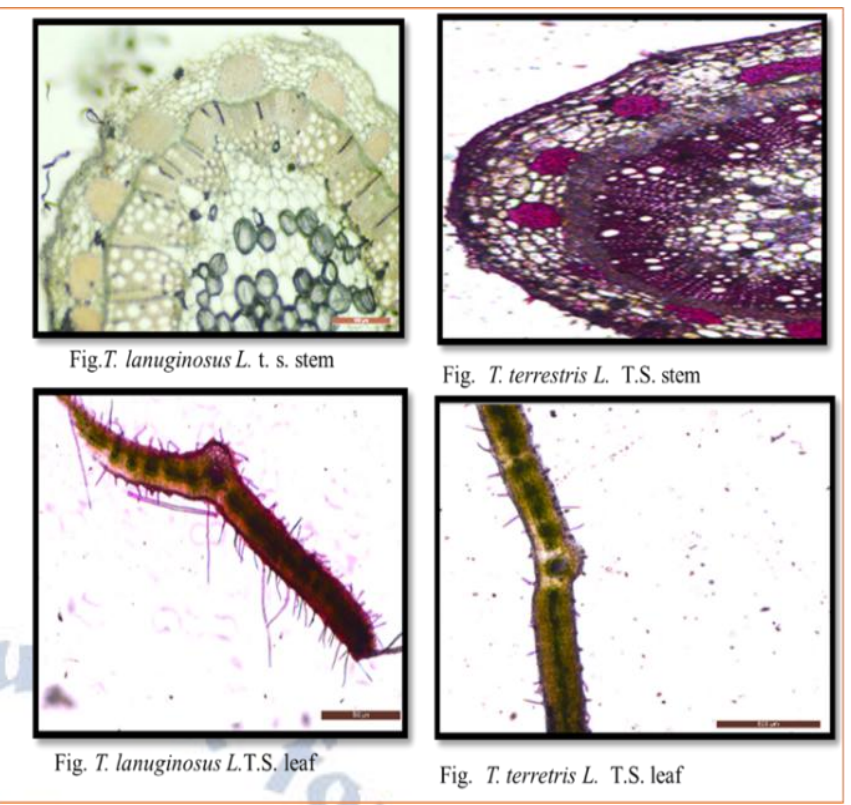

Plate 3: Anatomical Characters of Tribulussps.

Table 2: Anatomical Similarities andDifferences between Tribulussps.

\section{Name of the T.terretrisL. T.lanuginosusL.}

plant

T.S.Stem 1.One layer of polygonal epidermal cell with

Similarities thick cuticle.

1.One layer of polygonal epidermal cell with thick cuticle.

2. The fascicular cambium is connected with the 2 . The fascicular cambium is connected with the interfascicular cambium forming a complete interfascicular cambium forming a complete vascular cambium ring of 3-5 cells thick.

vascular cambium ring of 3-5 cells thick.

\begin{tabular}{lll}
\hline Differences & $\begin{array}{l}\text { The cortex consists of 1-2 layers of thick } \\
\text { parenchyma. }\end{array}$ & $\begin{array}{l}\text { The cortex consists of 2-3 layers of thick } \\
\text { parenchyma. }\end{array}$ \\
\hline $\begin{array}{l}\text { T.S. leaf } \\
\text { Similarities }\end{array}$ & $\begin{array}{l}\text { 1.Unicellular trichomes. } \\
\text { 2. Reduced stomata. }\end{array}$ & $\begin{array}{l}\text { 1.Unicellular trichomes. } \\
\text { 2. Reduced stomata. }\end{array}$ \\
\hline Differences & Epidermal hairs are not dense. & Epidermal hairs are denser. \\
\hline
\end{tabular}

Table 3: Preliminary phytochemical screening of sample extract

\begin{tabular}{|c|c|c|c|c|c|}
\hline $\begin{array}{l}\text { Sr. } \\
\text { No. }\end{array}$ & $\begin{array}{l}\text { Phytochemical } \\
\text { test }\end{array}$ & $\begin{array}{l}\text { TT whole } \\
\text { plant }\end{array}$ & TT fruit & $\begin{array}{l}\text { TL whole } \\
\text { plant }\end{array}$ & TL fruit \\
\hline 1 & Alkaloid & 2 & & & \\
\hline $\mathrm{a}$ & Mayer's test & + & - & + & + \\
\hline $\mathrm{b}$ & Wagner's test & -4 & 10 & + & + \\
\hline c & Hager's test & + & - & + & + \\
\hline 2 & Starch & + & + & + & + \\
\hline 3 & Carbohydrate & + & + & + & + \\
\hline 4 & Tannin & + & + & + & + \\
\hline 5 & Saponin & + & + & + & + \\
\hline 6 & Glycoside & + & - & + & + \\
\hline 7 & Phenol & + & + & + & + \\
\hline 8 & Flavonoid & + & + & + & + \\
\hline 9 & Protein & + & + & + & + \\
\hline
\end{tabular}

Note: TT:T. terrestris; TL:T. lanuginosus(+) indicates present, (-) indicates absent 


\section{Qualitative phytochemical analysis}

The usefulness of phytochemical analysis in the discovery of therapeutically active and industrially valuable chemicals is well known. Analyzing these phytochemicals in various medicinal plants allows scientists to gain a better understanding of the chemical composition of plants, which leads to the development of new medicines (Banu and Cathrine, 2015; Dhale, 2016). Flavoring, insecticides, aroma, sweeteners, natural dyes, medicinal properties, and other primary and secondary substances The current research were carried out for the screening of phytochemicals contained in certain plant sections, keeping in mind the importance of this primary and secondary compound. Powder sample of T. terrestris, T. lanuginosus, showed the presence of carbohydrates, Protein, Phenol, Starch, Alkaloids, Glycosides, Flavonoid, Tannin, and Saponins by qualitative tests. Which added to its potential as a bioactive principle. Results of preliminary phytochemical analysis of various extracts are given in the Table 3.

\section{CONCLUSION}

Fruit, style, leaves, and stem morphological variations were discovered in the Tribulussps. investigated. The style of T. terretris and T. lanuginosus is glabrous. Upper and lower pairs of spines are present in T. terretris fruit as well. In T. lanuginosus, this was either absent or greatly reduced. T. terretris and T. lanuginosus have substantially smaller leaves.The anatomical properties of the stem and leaf in the two species tested exhibited modest changes. The pith of $T$. terretris is wider than that of T. lanuginosus, which was narrow. Xeromorphic modifications can be seen on the leaflet. In comparison to T. terretris, leaf sections demonstrate the presence of unicellular trichomes that are substantially denser in $T$. lanuginosus.It was found that the phytochemical constituents such as alkaloids, starch, carbohydrates, tannin, saponins, glycosides, phenol, flavonoids, and proteins showed presence in various tests for qualitative analysis of different Tribulussps.

\section{REFERENCES}

[1] Banu K.S. and Cathrine L. (2015) General Techniques involved in phytochemical analysis, International journal of advanced research in chemical science (IJARCS) vol.2 issue 4 pp. 25-32.
[2] Dhale D. A. (2011) Histochemical Investigation of Some Medicinal Plants, Adv. R. Pharm. and Biol., Vol 1(2): 147-154.

[3] Dhale D. A. (2016) Medico-botanical assessment of a weed plant: Cassia obtusifolia, International Journal of Agricultural Invention, Vol.1(2):201-206

[4] Dhale D. A. andR.K. Kalme (2012) Pharmacognostic Characterization of Stem and Root of AdhatodazeylanicaMedicus, Int J Pharm Sci Res., Vol. 3(11): 4264-4269

[5] Dhale D. A., Markandeya S. K. and Y.D. Niturkar (2010) Standardization of Homoeopathic Drug Rutagraveolens L., J Phytol., Vol. 2(3):01-07

[6] Elkamali H.H., Eltahir S.E., Yousif I.S., Khalid A.H.H. andElneed E.A. (2016) Comparative anatomical study of the stems and leaflets of Tribuluslongipetalus, $T$. pentandrusand T. terretris(Zygophyllaceae), open-access library journal, 3:e2810.

[7] Fransworth B. (1960)Hanbuch der Drogenkunde, Wilhelm MaudrichVerlag, Wein.Band, V: 297-298.

[8] Harborne J. B. (1973) phytochemical methods: A guide to modern techniques of plant analysis. Chapman and Hall Ltd, London. Pp. 279.

[9] Homersleg F. E. (1950)The technology and chemistry of alkaloids, D.Van. NostrandCompany, Inc. New York.

[10] Naik V.N. (1998), "Flora of Marathwada", Volume 1. Amrutprakashan, Aurangabad.

[11] Nayar and Giri (1982), A synopsis of Genus Tribulus L. In india bulletin of botanical survey of India volume 24, NOS. 1-4 : pp. 160-164,

[12] Peach K. and Tracy, K.V. (1955) Modem Methods of Plant Analysis. Springer Verlag Berlin 2: 153-154.

[13] Porter D. (1971) Notes on the Floral Glands in Tribulus (Zygophyllaceae). Annals of the Missouri Botanical Garden, 58(1), 1-5. doi:10.2307/2394924

[14] Singh N. P.and S. Karthikeyan (Eds). (2000) Flora of Maharashtra State Dicotyledones. Vol (2). Bot. Surv. India, Kolkata.

[15] Trease G. C. and Evans, W. C. (1972)Pharmacognosy, Bailliere Tindall and Cassell,London, 10' edn.: 541-547.

[16] Trease G. C. and Evans, W.C. (2002) Pharmacognosy. $5^{\text {th }}$ Edn. W. B. Saunders, Edinburgh, London, New York, Philadelphia, St. Louis, Sydney, Toronto: 1-5,333.

[17] Treas, G. E. and Evans W.C. (1983) Textbook of pharmacognosy. $12^{\text {th }}$ Edition, Tindall and Co., London, 343-383. 